\title{
OPIEKA PIELĘGNIARSKA NAD PACJENTEM Z NIEDROBNOKOMÓRKOWYM RAKIEM PŁUCA - STUDIUM PRZYPADKU
}

\section{NURSING CARE OF THE PATIENT WITH NON-SMALL CELL LUNG CANCER - CASE STUDY}

\author{
Kinga Nalewaj ${ }^{1}$, Anna Zera ${ }^{2}$, Andrzej Krupienicz ${ }^{2}$ \\ absolwentka studiów licencjackich, Wydział Nauki o Zdrowiu \\ Warszawski Uniwersytet Medyczny \\ ${ }^{2}$ Zakład Podstaw Pielegniarstwa \\ Warszawski Uniwersytet Medyczny
}

DOI: https://doi.org/10.20883/pielpol.2018.27

\begin{abstract}
STRESZCZENIE
Wprowadzenie. Główną przyczyną rozwoju raka płuca jest palenie papierosów. Dym tytoniowy składa się z prawie kilku tysięcy substancji chemicznych, z czego kilkadziesiąt to substancje rakotwórcze. Na raka płuca mogą zachorować osoby, które nigdy nie paliły, a były narażone na wdychanie dymu tytoniowego. Nowotwory złośliwe płuca, zwłaszcza rak niedrobnokomórkowy, rozwijają się bardzo wolno, charakterystyczne objawy występują przeważnie wtedy, gdy obecne są zmiany metastatyczne, czyli przerzutowe. Rokowanie chorych na pierwotne nowotwory płuca jest złe, dlatego należy dążyć do tego, aby ograniczyć ekspozycję na działanie dymu tytoniowego i innych szkodliwych czynników. Cel. Celem pracy była ocena sytuacji zdrowotnej, określenie problemów pielęgnacyjnych oraz zaplanowanie opieki nad pacjentem chorującym na niedrobnokomórkowego raka płuca.

Opis przypadku. W pracy przedstawiono 46-letniego pacjenta chorującego na niedrobnokomórkowego raka płuca w zaawansowanym stadium, z przerzutami w obu płucach, wątrobie, nadnerczach, kościach i móżdżku oraz chorobami współistniejącymi: schizofrenią paranoidalną i toczniem rumieniowatym układowym. Uwzględniono funkcjonowanie chorego w sferze biologicznej, psychicznej oraz społecznej, które stanowią integralną całość. Wnioski. Opieka pielegniarska nad pacjentem z niedrobnokomórkowym rakiem płuca o niepomyślnym rokowaniu powinna być całościowa i uwzględniać sferę biologiczną, społeczną, psychiczną i duchową.
\end{abstract}

SŁOWA KLUCZOWE: niedrobnokomórkowy rak płuca, opieka pielęgniarska.

\section{Wprowadzenie}

Układ oddechowy odgrywa istotną rolę w życiu człowieka. Umożliwia pobieranie tlenu z otoczenia, który drogami oddechowymi transportowany jest do krwi, a wraz z krwią do całego ciała, a także wydalanie dwutlenku węgla - produktu przemiany materii. Układ oddechowy umożliwia także utrzymanie równowagi kwasowo-zasa-

\begin{abstract}
Introduction. The main cause of the lung cancer evolution is smoking cigarettes. Nicotine smoke is composed of almost a few thousand chemical substances, out of which a few hundred are carcinogenic. People who have never smoked but have been exposed to nicotine also can suffer from the lung cancer. Malignant tumours especially non-small cell lung cancer are developing very slowly, characteristic symptoms appear mostly when metastatic lesions are present. Prognoses are very bad, therefore it is necessary to limit exposure to nicotine and other harmful factors.

Aim. The aim of the study was to assess of the health situation, identify care problems and plan the nursing care of the patient with non-small cell lung cancer.

Case description. In this case study a 46-year old patient who suffered from non-small cell lung cancer at the advanced stage with metastatic in both lungs, liver, adrenals, bones, cerebellum and other diseases: paranoid schizophrenia and systemic lupus erythematosus was presented. Moreover, the patient functioning in biological, psychical and social spheres as a whole was included in the study.

Conclusions. Nursing care of the patient with non-small cell lung cancer with the unsuccessful prognosis should be holistic and take into account the biological, social, mental and spiritual spheres.
\end{abstract}

KEYWORDS: non-small cell cancer lungs, nursing care.

dowej, a dzięki makrofagom, rzęskom obecnym w nabłonku, a także immunoglobulinom działa jako obrona przed czynnikami szkodliwymi, poprzez usuwanie ich na zewnątrz. Z wdychanym powietrzem dostają się do układu oddechowego substancje toksyczne, szkodliwe dla ludzkiego organizmu, co powoduje często rozwój chorób nowotworowych, takich jak rak jamy ustnej, prze- 
łyku, krtani, płuca. Od wielu lat to właśnie raki oskrzela i płuca są na pierwszym miejscu pod względem występowania nowotworów, a same nowotwory znajdują się na drugim miejscu przyczyn zgonu wśród Polaków. Głównym czynnikiem rozwoju raka płuca jest palenie papierosów. Dym tytoniowy składa się z prawie kilku tysięcy substancji chemicznych, z czego kilkadziesiąt to substancje rakotwórcze. Najważniejsze z nich to policykliczne węglowodory aromatyczne, N-nitrozoaminy, aminy aromatyczne, polon 210 . Niestety, na raka płuca mogą zachorować osoby, które nigdy nie paliły, a były narażone na wdychanie dymu tytoniowego. Palenie bierne równe jest paleniu czynnemu pod względem ryzyka zachorowania na raka płuca [3-5].

Innymi czynnikami rakotwórczymi, oprócz palenia papierosów, mogą być nieprawidłowe nawyki żywieniowe, obecność szkodliwych substancji w środowisku, spaliny samochodowe, zanieczyszczenia pochodzące z fabryk, metale radioaktywne i gazowe produkty ich rozpadu, a także czynniki genetyczne. Większość palaczy ignoruje pierwsze objawy choroby, które są mało specyficzne. Choroba we wczesnym stadium wykrywana jest przypadkowo, zazwyczaj podczas badania rentgenowskiego, które najczęściej wykazuje cień we wnęce płuca. Często cień na zdjęciu RTG mylony jest z wadą kliszy, dlatego też objaw ten jest ignorowany. Rak płuca jest diagnozowany w takim stadium, w którym jedyne leczenie, jakie można zastosować, to leczenie paliatywne poprawiające komfort życia. Nowotwory złośliwe płuca, zwłaszcza rak niedrobnokomórkowy, rozwijają się bardzo wolno, charakterystyczne objawy występują przeważnie wtedy, gdy obecne są zmiany metastatyczne, czyli przerzutowe. Rokowanie chorych na pierwotne nowotwory płuca jest złe, dlatego należy dążyć do tego, aby ograniczyć ekspozycję na działanie dymu tytoniowego i innych szkodliwych czynników [6].

Nowotwory płuca są największym zagrożeniem zdrowia zarówno kobiet, jak i mężczyzn. Społeczeństwo zdaje sobie sprawę z negatywnych skutków palenia papierosów, jednak uzależnienie jest tak silne, że niemożliwe staje się zwalczenie nałogu, zwłaszcza gdy palenie papierosów trwa od wieku młodzieńczego. Układ oddechowy jest bardzo ważny dla życia człowieka, dlatego należy dbać o jego prawidłowe funkcjonowanie, chociażby poprzez zaprzestanie palenia [7].

Planując opiekę nad chorym z niedrobnokomórkowym rakiem płuca, uwzględniono funkcjonowanie pacjenta w sferze biologicznej, psychicznej oraz społecznej, które stanowią integralną całość. Wiedza na temat postępowania z pacjentem onkologicznym jest bardzo ważna, gdyż pielęgniarka może się spotkać na każdym oddziale z pacjentem z chorobą nowotworową, niekoniecznie płuca $[8,9]$.

\section{Opis przypadku}

Czterdziestosześcioletni chory, z wykształceniem średnim, od 18 lat był na rencie. Przed przejściem na rentę inwalidzką pełnił służbę w instytucji państwowej. Pacjent od 30 lat palił jedną paczkę papierosów dziennie, skarżył się na częste bóle głowy i stawów. Miał problemy ze snem, często pił kawę, także w nocy, nie spożywał alkoholu. Nigdy nie narzekał na swoje życie. Podczas wizyty u lekarza podstawowej opieki zdrowotnej 3 lata temu otrzymał skierowanie na dalszą diagnostykę z powodu podwyższonej leukocytozy, OB i CRP. Chory zbagatelizował problem, stwierdził, że jest zdrowy i nie potrzebuje leczenia. Po 3 latach od pierwszych podejrzeń choroby mężczyzna zaczął opadać z sił, większość czasu spędzał w łóżku, każdy ruch powodował u niego dolegliwości bólowe, pojawiły się także: uporczywy kaszel, odkrztuszanie krwistej wydzieliny, bóle w klatce piersiowej i silne poty, także w nocy. Chory miał obniżony apetyt. Pojawiły się niechęć do życia, częste wahania nastroju, płacz. Waga spadła do $83 \mathrm{~kg}$, a wzrost obniżył się o $10 \mathrm{~cm}$. BMI wynosiło 27,4, co wskazywało na nadwagę. Chory zaobserwował tworzenie się ran na łokciach po długim opieraniu łokcia na twardej powierzchni. Cały czas chory był samodzielny i sprawny.

Mężczyzna z wywiadem nikotynowym, leczony dotąd na schizofrenię paranoidalną i toczeń rumieniowaty układowy, został przyjęty do Kliniki Reumatologii i Chorób Wewnętrznych w celu diagnostyki silnych bóli mięśni i stawów z parestezjami, chudnięcia (około $10 \mathrm{~kg}$ w ciągu 3 miesięcy), obniżenia wzrostu o $10 \mathrm{~cm}$, duszności, osłabienia. W badaniach laboratoryjnych nadal utrzymywała się podwyższona leukocytoza, OB oraz CRP. Ciśnienie tętnicze wynosiło 120/80 mmHg. Badanie EKG nie wykazało żadnych zaburzeń. Zdjęcie RTG klatki piersiowej wykazało zmiany guzkowe i pasmowate zagęszczenia szerzące się odwnękowo ku górze do obwodu z poszerzeniem wnęki prawej i w mniejszym stopniu lewej (Rycina 1). Sylwetka serca o zaakcentowanej lewej komorze, przepona wolna. Badanie RTG kręgosłupa lędźwiowego wykazało zanik kostny (Rycina 2). Wynik badania densytometrycznego kośćca osiowego spełnił kryteria osteoporozy wg WHO. Zostało wykonane badanie USG jamy brzusznej, które ujawniło powiększenie wątroby i torbiele korowe w obu nerkach. W toku przeprowadzonej diagnostyki na podstawie tomografii komputerowej klatki piersiowej i brzucha, bronchoskopii i badań dodatkowych rozpoznano guz wnęki płuca prawego z licznymi zmianami ogniskowymi o charakterze metastatycznym w obu płucach, wątrobie, nadnerczach i kościach. Chory był po konsultacji pulmonologicznej i onkologicznej. W porozumieniu z onkologiem ustalono, że chory zgłosi się do Poradni Onkologicznej z wynikami 
badania histopatologicznego celem ustalenia dalszego postępowania. Do leczenia zastosowano plastry Durogesic w dawce $25 \mu \mathrm{g}-1$ plaster przyklejany na skórę raz na 3 dni, Tramal retard $150 \mathrm{mg} 2 \times 1$ tabl., Medrol $16 \mathrm{mg}$ $1 / 2$ tabl. rano, Prazol 20 mg $1 \times 1$ tabl., Torecan czopki $1 \mathrm{w}$ razie nudności. Zalecono dietę lekkostrawną. Chory w stanie optymalnym został wypisany do domu.

Dwa tygodnie po zdiagnozowaniu choroby pacjent trafił do szpitala na Oddział Neurologiczny z powodu silnych zaburzeń świadomości, bełkotliwej mowy, wymiotów, zawrotów głowy i oblewających potów. Ciśnienie przy przyjęciu wyniosło 140/80 $\mathrm{mmHg}$, badania laboratoryjne wykazały podwyższone OB, leukocytozę i hiponatremię. Badanie EKG wykazało tachykardię zatokową $102 \mathrm{u} / \mathrm{min}$, pośrednią oś serca i niespecyficzne zmiany ST-T. W badaniu CT ośrodkowego układu nerwowego uwidoczniono w zakresie obu płatów móżdżku dość liczne hyperdensyjne, okrągławe zmiany z dyskretnym, obrączkowatym wzmocnieniem po kontraście, co wskazuje na meta do móżdżku. Struktury mózgu bez zmian ogniskowych. Chory w stanie dość dobrym z zaleceniami jak do tej pory został wypisany do domu.

Pacjent następnie został przyjęty do Kliniki Onkologii w trybie planowym celem kwalifikacji i rozpoczęcia leczenia chemioterapią o charakterze paliatywnym. Chory hospitalizowany przed 4 tygodniami w Klinice Reumatologii i Chorób Wewnętrznych, gdzie stwierdzono guz oskrzela górnopłatowego prawego oraz liczne zmiany przerzutowe w obu płucach, wątrobie, nadnerczach i kościach. Wykonano badanie bronchoskopowe, w którym uwidoczniono powyższy guz i pobrano wycinki. Wynik badania histopatologicznego: Carcinoma non microcellulare probabiliter adenocarcinoma - rak niedrobnokomórkowy prawdopodobnie gruczołowy. Tydzień później chory został napromieniony paliatywnie na obszar kręgosłupa Th11-L4 jednorazową dawką 800 cGy/t. W chwili przyjęcia do Kliniki stan chorego był dość dobry. W badaniu przedmiotowym wykryto ciastowate obrzęki podudzi, a także dyskretnie powiększoną wątrobę, poza tym bez istotnych zmian. Pacjent po kontroli badań otrzymał pierwszą część I kursu chemioterapii - schemat PG (cisplatyna $80 \mathrm{mg} / \mathrm{m}^{2}$, gemcytabina $1250 \mathrm{mg} / \mathrm{m}^{2}$ ) w skojarzeniu z Avastinem 7,5 mg/kg m.c. $2 \mathrm{~h}$ po zakończonej chemioterapii (lek z daru firmy farmaceutycznej). Wystąpiono do Narodowego Funduszu Zdrowia z wnioskiem o refundację dalszego leczenia bewacizumabem. Wczesna tolerancja zastosowanego leczenia była dość dobra. Pod koniec wlewu gemcytabiny pojawiła się umiarkowana duszność, która ustąpi- ła po podanych lekach. Po zastosowaniu leków diuretycznych ustąpiły również całkowicie obrzęki podudzi. W stanie ogólnym zadowalającym pacjenta wypisano do domu z zaleceniami: oszczędzający tryb życia, spożywanie 1,5-2 I płynów na dobę, leki: Durogesic $50 \mu \mathrm{g} / \mathrm{h}$, zmiana plastra co $72 \mathrm{~h}$, MST Cont $10 \mathrm{mg} 2 \times 1$ tabl./dobę, Dexamethason $1 \mathrm{mg} 2 \times 2$ tabl./dobę, Prazol 20 mg 1 tabl. rano, Kalipoz $2 \times 1$ tabl./dobę, Tritace $5 \mathrm{mg}$ p.o./dobę, Relanium $5 \mathrm{mg} 2 \times 1$ tabl./dobę, Sulpiryd 50 mg $2 \times 1$ tabl./dobę, Atarax 25 mg 2 tabl. na noc, Nystatyna do płukania jamy ustnej $2 \times$ na dobę, w razie nudności bądź wymiotów Zofran 8 mg 2 x 1 tabl./dobę, w razie biegunki Loperamid 2 tabl. +1 tabl. po każdym luźnym stolcu (maks. 8 tabl./dobę), Spironol $252 \times 1$ tabl./dobę.

Półtora tygodnia po zastosowanym leczeniu paliatywnym chory został przywieziony przez Zespół Ratownictwa Medycznego do Szpitalnego Oddziału Ratunkowego z powodu wysokiej gorączki, oblewających potów, kaszlu, duszności i zawrotów głowy. Wykonano podstawowe badania, według których zdiagnozowano zapalenie płuc. Pacjent trafił na Oddział Chorób Wewnętrznych, w następnej dobie zmarł. Przyczyną bezpośrednią zgonu było zatrzymanie krążenia. Przyczyną wtórną zgonu był obrzęk płuc w przebiegu zapalenia płuc, przyczyną wyjściową - nowotwór złośliwy płuca prawego.

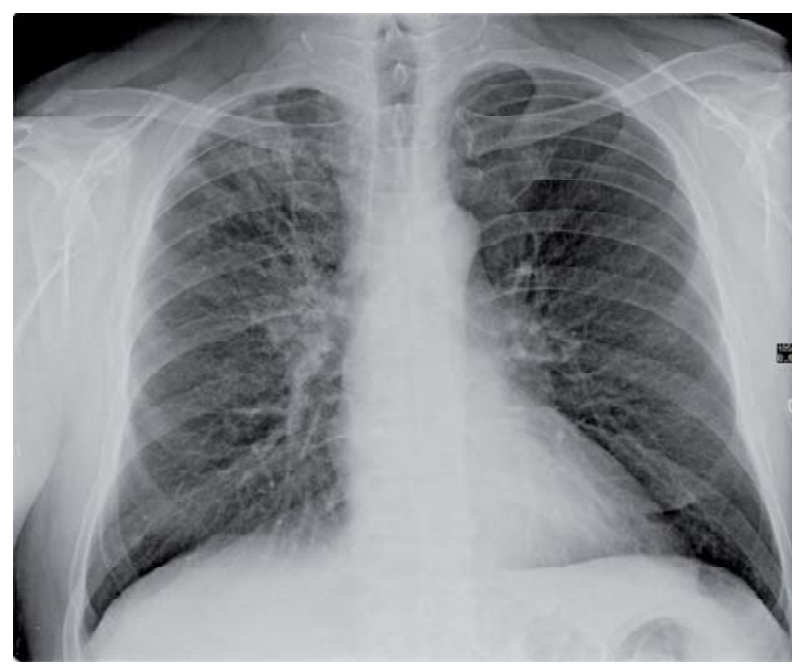

Rycina 1. Zdjęcie RTG klatki piersiowej, na którym widoczne są zmiany guzkowe i zagęszczenia pasmowate szerzące się odwnękowo ku górze do obwodu z poszerzeniem wnęki prawej i w mniejszym stopniu lewej (zdjęcie oryginalne)

Figure 1. X-ray image of chest showing nodular lesions and strand densities spreading from recess upwardly to the perimeter with widening the right and less left recess (original image) 


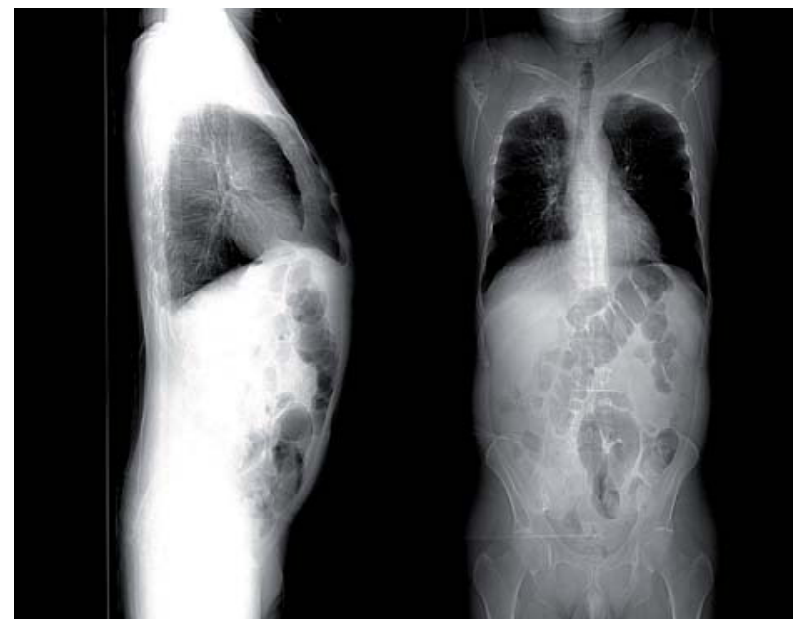

Rycina 2. Zdjęcie przeglądowe jamy brzusznej i klatki piersiowej wykonane w projekcji bocznej i przednio-tylnej, wyraźne zaniki kostne (zdjęcie oryginalne)

Figure 2. X-ray image of abdominal cavity and chest done in the lateral and anteroposterior projection. Visible bone atrophy (original image)

\section{Problemy pielęgnacyjne [9-13]}

\section{Dolegliwości bólowe w klatce piersiowej,} okolicy lędźwiowej, bóle mięśni i stawów w przebiegu niedrobnokomórkowego raka płuca

Cel opieki: zmniejszenie dolegliwości bólowych, poprawa komfortu życia chorego.

Planowane działania:

- Monitorowanie i ocena natężenia bólu przy wykorzystaniu VAS lub skali numerycznej.

- Ocena objawów towarzyszących, które mogą nasilać ból.

- Podanie leków wg zleceń lekarskich, ocena skuteczności i obserwacja w kierunku wystąpienia objawów niepożądanych.

- Usunięcie bodźców narażających chorego na dodatkowy ból.

- Zapewnienie bezpieczeństwa.

- Zastosowanie technik relaksacyjnych.

\section{Ryzyko wystąpienia powikłań z powodu zapalenia płuc}

Cel opieki: złagodzenie objawów, poprawa samopoczucia. Planowane działania:

- Obserwacja chorego, jego potrzeb i ich realizacja.

- Zapewnienie bezpieczeństwa choremu i obecności przy nim.

- Podanie leków wg zleceń lekarskich.

- Kontrola objawów i dolegliwości bólowych.

- Zastosowanie drenażu ułożeniowego.

\section{Obniżenie apetytu i ryzyko wystąpienia} niedożywienia

Cel opieki: poprawa łaknienia, zapobieganie wystąpieniu niedożywienia.

Planowane działania:

- Ocena stanu odżywienia chorego.

- Ustalenie zapotrzebowania na składniki odżywcze i witaminy.

- Wprowadzenie odpowiedniej do stanu zdrowia diety uwzględniającej niezbędne składniki odżywcze, błonnik i witaminy, a także preferencje żywieniowe chorego.

- Doprawianie potraw do smaku.

- Jedzenie przez chorego 4-5 posiłków dziennie co 3-4 godziny, możliwie o tych samych porach.

- Uwzględnienie odpowiedniej podaży płynów.

- Mobilizacja chorego do przestrzegania pory posiłków i zjadania całych porcji.

- Przedstawienie zalet i wad regularnego spożywania posiłków.

4. Ryzyko wystąpienia niedotlenienia w związku z dusznością spowodowaną zablokowaniem dróg oddechowych w przebiegu NDRP

Cel opieki: zlikwidowanie duszności. Zapewnienie bezpieczeństwa. Zmniejszenie ryzyka niedotlenienia.

Planowane działania:

- Ocena rodzaju duszności.

- Ułożenie wysokie chorego, poluzowanie odzieży pod szyją.

- Pomiar wysycenia krwi tlenem za pomocą pulsoksymetru.

- W razie potrzeby podanie tlenu.

- Zapewnienie dostępu do świeżego powietrza, przewietrzenie sali chorego.

\section{Nieefektywne odkrztuszanie spowodowane nadmierną produkcją śluzu, obecnością wydzieliny zapalnej $\mathrm{i}$ krwi w drogach oddechowych}

Cel opieki: zmniejszenie nasilenia i częstotliwości kasz-

lu. Nauka efektywnego odkrztuszania.

Planowane działania:

- Nauka ćwiczeń oddechowych i efektywnego odkrztuszania.

- W miarę możliwości zapewnienie choremu ruchu.

- Zastosowanie inhalacji, nawilżenie powietrza.

- Podanie leków wg zleceń.

- Zapewnienie bezpieczeństwa, zmniejszenie lęku. 


\section{Zaleganie krwistej wydzieliny w drogach oddechowych. Krwioplucie}

Cel opieki: oczyszczenie drzewa oskrzelowego z zalegającej wydzieliny. Zapobieganie powikłaniom.

Planowane działania:

- Ułożenie pacjenta tak, aby nie doszło do aspiracji wydzieliny do dalszych części drzewa oskrzelowego i pęcherzyków płucnych.

- Nauka efektywnego odkrztuszania i usuwania wydzieliny z drzewa oskrzelowego.

- Zmniejszenie lęku.

\section{Zagrożenie odwodnieniem z powodu nadmiernej} potliwości, uderzeń gorąca i gorączki

Cel opieki: obniżenie temperatury ciała do poziomu $36,6-36,8^{\circ} \mathrm{C}$, zmniejszenie ryzyka odwodnienia chorego. Zapewnienie komfortu i bezpieczeństwa.

Planowane działania:

- Regularna kontrola temperatury ciała.

- Zastosowanie lekkiego okrycia, przewiewnego ubrania i podawanie chłodnych, ale nie zimnych napojów.

- Wymiana bielizny osobistej i pościelowej na suchą bawełnianą.

- $\quad$ Obniżenie temperatury w pomieszczeniu, zmiana mikroklimatu.

- Zastosowanie chłodnych kąpieli, dokładne osuszanie skóry.

- Podanie leków przeciwgorączkowych i innych wg zleceń lekarskich.

- Obserwacja i kontrola stanu nawodnienia chorego.

\section{Ryzyko złamania kości w związku \\ z zanikami kostnymi i osteoporozą w chorobie nowotworowej}

Cel opieki: zmniejszenie ryzyka złamania kości.

Planowane działania:

- Wyjaśnienie choremu, na czym polega osteoporoza, jakie są jej objawy i co może nasilać demineralizację kości.

- Wprowadzenie diety zawierającej właściwą do wieku i stanu zdrowia ilość witaminy D i wapnia.

- Farmakoterapia zgodnie ze zleceniami.

- Edukacja w zakresie wpływu używek, takich jak: kawa i papierosy na stan kości.

- Eliminacja ryzyka upadków i urazów poprzez zapewnienie bezpieczeństwa podczas wykonywania danych czynności.

- Wykonywanie ćwiczeń ruchowych wzmacniających układ kostno-stawowy.

\section{Ryzyko wystąpienia odczynu popromiennego na skórze w wyniku stosowanej radioterapii}

Cel opieki: zmniejszenie ryzyka wystąpienia odczynu popromiennego.

Planowane działania:

- Ocena ryzyka wystąpienia odczynu popromiennego.

- Obserwacja skóry.

- Edukacja chorego w zakresie higieny miejsc napromienianych.

- Unikanie zbyt długiego przebywania w wodzie, mycie chorego letnią wodą pod prysznicem, stosowanie środków neutralnych dla skóry bez substancji zapachowych.

- Delikatne osuszanie i nawilżanie miejsc napromienianych, unikanie silnego tarcia.

- Unikanie długiego przebywania na słońcu.

\section{Obniżenie nastroju, depresja, zmęczenie}

Cel opieki: poprawa nastroju.

Planowane działania:

- Nawiązanie kontaktu z chorym, poprowadzenie rozmowy, zachęcanie do mówienia o tym, co pacjent przeżywa, co go dręczy.

- Podkreślanie pozytywnych cech chorego.

- Pomoc w rozwijaniu zainteresowań.

- Podanie leków uspokajających wg zlecenia.

\section{Dyskusja}

Zaprezentowano przypadek mężczyzny - rencisty w wieku produkcyjnym, chorującego na niedrobnokomórkowego raka płuca, który od najmłodszych lat palił dużą liczbę papierosów dziennie. Poza tym jako mieszkaniec dużego miasta, a zwłaszcza dawnej dzielnicy robotniczej - Woli, narażony był na obecność szkodliwych substancji, zanieczyszczeń pochodzących z dawnych fabryk oraz spalin samochodowych. Niewątpliwie wpływ na rozwój choroby miały czynniki genetyczne, schorzenia współistniejące: toczeń rumieniowaty układowy i schizofrenia paranoidalna.

Główną substancją szkodliwą w papierosach jest nikotyna - alkaloid przyswajalny przez człowieka, metabolizowany w szybkim tempie i wydalany przez nerki. Nikotyna powoduje biologiczne uzależnienie palacza. Dochodzi do zwiększenia głębokości i częstości oddechów, a dużo większe jej dawki porażają ośrodek oddechowy w rdzeniu przedłużonym. Ponadto dym tytoniowy zawiera substancje powodujące zwężenie oskrzeli, kaszel, osłabienie ruchu rzęsek, przez co upośledza funkcje wydalania obcych substancji z układu oddechowego i przyczynia się do częstych infekcji [2]. 
NDRP w początkowym stadium nie daje żadnych charakterystycznych objawów. Na podstawie badania krwi, które wykazało podwyższoną leukocytozę, OB oraz białko C-reaktywne, lekarz zlecił dalszą diagnostykę w kierunku potencjalnego nowotworu. Bagatelizacja problemu przez chorego doprowadziła do poważnego rozwoju choroby w ciągu 3 lat od pierwszych podejrzeń i pojawienia się konkretnych objawów: suchego, męczącego kaszlu, odkrztuszania krwistej wydzieliny, duszności, bólu w klatce piersiowej, chrypki, znacznej utraty masy ciała, bóli mięśni i stawów. Pojawiły się też objawy świadczące o wystąpieniu przerzutów do obu płuc, wątroby, nadnerczy, kości i móżdżku. Kliniczny obraz choroby nie dał możliwości zastosowania innego leczenia u chorego niż leczenie paliatywne, mające na celu zmniejszenie dolegliwości bólowych, złagodzenie objawów choroby i poprawę komfortu życia. W leczeniu objawowym zastosowano napromienianie paliatywne i pierwszą część I kursu chemioterapii wg schematu (cisplatyna + gemcytabina) w skojarzeniu z bewacizumabem. Ponadto chory przyjmował szereg leków m.in. z grupy: opioidów, glikokortykosteroidów, leki przeciwwymiotne, potas, lek z grupy przeciwpsychotycznych I generacji.

Podczas planowania opieki pielęgniarskiej nad pacjentem onkologicznym uwzględniono najważniejsze problemy pielęgnacyjne w każdej sferze jego funkcjonowania. Zaproponowano działania mogące ulżyć choremu oraz zapewnić mu godne życie w ostatnich chwilach. Bardzo ważna jest znajomość sposobu prowadzenia opieki pielęgniarskiej nad pacjentem onkologicznym i jego rodziną, ponieważ na każdym oddziale znajdzie się pacjent, który ma nowotwór, niekoniecznie płuca [7].

Problem palenia papierosów, a także wdychania dymu tytoniowego dotyczy każdej grupy wiekowej, nawet najmłodsi zaczynają sięgać po tę używkę, co może przynieść bardzo niekorzystne skutki w przyszłości. Ciężka droga, jaką przebył pacjent w chorobie od momentu jej wykrycia do śmierci, nie jest warta żadnego wypalonego papierosa, dlatego należy zastanowić się, czy warto po niego sięgać.

\section{Piśmiennictwo}

1. Gilligan D, Rintoul R. Rak płuc. Tłum. S. Janeczek. Warszawa: PZWL; 2010.

2. Kołodziej J, Marciniak M (red.). Rak płuca. Poznań: Termedia Wydawnictwa Medyczne; 2010.

3. Didkowska J, Wojciechowska U. Zachorowania i zgony na nowotwory złośliwe w Polsce. Krajowy Rejestr Nowotworów, Centrum Onkologii - Instytut im. Marii Skłodowskiej-Curie, http://onkologia.org.pl/k/epidemiologia/ (data dostępu: 11.11.2016).

4. Krzakowski M, Potemski P, Warzocha K, Wysocki P (red.). Onkologia kliniczna. Tom I. Gdańsk: Wydawnictwo Via Medica; 2015.

5. Potemski P. Rak płuca. W: Kordek R (red.). Onkologia. Podręcznik dla studentów i lekarzy. Gdańsk: Wydawnictwo Via Medica; 2013: 134-145.

6. Frączak M (red.). Podstawy diagnostyki i terapii nowotworów. Bielsko-Biała: Wydawnictwo Alfa Medica; 2008.

7. Koper A (red.). Pielęgniarstwo onkologiczne. Podręcznik dla studiów medycznych. Warszawa: PZWL; 2011.

8. De Walden-Gałuszko K, Kaptacz A (red.). Pielęgniarstwo opieki paliatywnej. Warszawa: PZWL; 2017.

9. Kózka M, Płaszewska-Żywko L (red.). Diagnozy i interwencje pielęgniarskie. Podręcznik dla studiów medycznych. Warszawa: PZWL; 2008.

10. De Walden-Gałuszko K, Ciałkowska-Rysz A (red.). Medycyna paliatywna. Warszawa: PZWL; 2015.

11. Ślusarska B, Zahradniczek K, Zarzycka D (red.). Podstawy pielęgniarstwa. Podręcznik dla studentów i absolwentów kierunków pielęgniarstwo i położnictwo. Tom I. Założenia teoretyczne. Warszawa: PZWL; 2014.

12. Ślusarska B, Zahradniczek K, Zarzycka D (red.). Podstawy pielęgniarstwa. Podręcznik dla studentów i absolwentów kierunków pielęgniarstwo i położnictwo. Tom II. Wybrane działania pielęgniarskie. Warszawa: PZWL; 2015.

Artykuł przyjęty do redakcji: 06.07.2017

Artykuł przyjęty do publikacji: 16.01.2018

Źródło finansowania: Praca nie jest finansowana z żadnego źródła. Konflikt interesów: Autorzy deklarują brak konfliktu interesów.

\author{
Adres do korespondencji: \\ Anna Zera \\ ul. Erazma Ciołka 27 \\ 01-445 Warszawa \\ tel./fax: 228360971 \\ e-mail: azera@wum.edu.pl \\ Zakład Podstaw Pielęgniarstwa, Wydział Nauki o Zdrowiu \\ Warszawski Uniwersytet Medyczny
}

